\title{
Aberrant cell cycle checkpoint function and early embryonic death in $\mathrm{Chk1}^{-/-}$mice
}

\author{
Hiroyuki Takai, ${ }^{1,6}$ Kaoru Tominaga, ${ }^{1,6,7}$ Noboru Motoyama, ${ }^{1,8}$ Yohji A. Minamishima, ${ }^{2,4}$ \\ Hiroyasu Nagahama, ${ }^{2,4}$ Tadasuke Tsukiyama, ${ }^{2,4}$ Kyoji Ikeda, ${ }^{1}$ Keiko Nakayama, ${ }^{3,4}$ \\ Makoto Nakanishi, ${ }^{1,5,8}$ and Kei-ichi Nakayama ${ }^{2-4}$ \\ ${ }^{1}$ Department of Geriatric Research, National Institute for Longevity Sciences, Aichi 474-8522, Japan; ${ }^{2}$ Department \\ of Molecular and Cellular Biology and ${ }^{3}$ Laboratory of Embryonic and Genetic Engineering, Medical Institute \\ of Bioregulation, Kyushu University, Fukuoka 812-8582, Japan; ${ }^{4}$ CREST, Japan Science and Technology Corporation, \\ Saitama 332-0012, Japan; ${ }^{5}$ Department of Biochemistry, Nagoya City University Medical School, Nagoya 467-8601, Japan
}

\begin{abstract}
The recent discovery of checkpoint kinases has suggested the conservation of checkpoint mechanisms between yeast and mammals. In yeast, the protein kinase Chk1 is thought to mediate signaling associated with the DNA damage checkpoint of the cell cycle. However, the function of Chk1 in mammals has remained unknown. Targeted disruption of Chk1 in mice showed that $C h k 1^{-/-}$embryos exhibit gross morphologic abnormalities in nuclei as early as the blastocyst stage. In culture, $\mathrm{Chk1}^{-/-}$blastocysts showed a severe defect in outgrowth of the inner cell mass and died of apoptosis. DNA replication block and DNA damage failed to arrest the cell cycle before initiation of mitosis in $\mathrm{Chk1}^{-/-}$embryos. These results may indicate that Chk1 is indispensable for cell proliferation and survival through maintaining the $G_{2}$ checkpoint in mammals.
\end{abstract}

[Key Words: Chk1; embryonic lethality; $\mathrm{G}_{2}$ checkpoints; abnormal nuclei; apoptosis]

Received March 15, 2000; revised version accepted May 1, 2000.

The transmission of genetic information relies on checkpoint responses to errors affecting the integrity, replication, and segregation of the genome. Detection of certain errors results in the relay of a signal (or signals) to effector molecules that implement checkpoint-dependent responses such as cell cycle arrest (Hartwell and Weinert 1989; Nurse 1994; Carr 1996). Such a delay in the cell cycle gives the cell time to repair damaged DNA or to complete DNA replication before mitotic segregation takes place. Thus, a defect in checkpoint mechanisms can result in genomic instability and lead to the transformation of normal cells into cancer cells. Many genes that contribute to checkpoint mechanisms were initially identified in fission or budding yeast as a result of mutations that disrupt cell cycle checkpoints (Al-Khodairy and Carr 1992; Elledge 1996). One of the ultimate targets of the checkpoint signaling pathways is the cyclin $\mathrm{B}-\mathrm{Cdc} 2$ complex, whose activity is essential for both the $\mathrm{G}_{2}-\mathrm{M}$ transition of the cell cycle and completion of mitosis (Enoch and Nurse 1990). The presence of checkpoint genes in distantly divergent eukaryotes suggests that certain checkpoint mechanisms may be conserved throughout evolution.

\footnotetext{
${ }^{6}$ These authors contributed equally to this work.

${ }^{7}$ Present address: Huffington Center on Aging, Baylor College of Medicine, One Baylor Plaza, Houston, TX 77030, USA.

${ }^{8}$ Corresponding author.

E-MAIL mkt-naka@med.nagoya-cu.ac.jp; FAX 81528423955.

E-MAIL motoyama@nils.go.jp; FAX 81562446595.
}

Chk1 was first identified in fission yeast as an essential kinase for cell cycle arrest induced by DNA damage (Walworth et al. 1993). Chk1 is phosphorylated in response to DNA damage (Walworth and Bernards 1996) in a manner dependent on the function of several Rad gene products, including Rad3, a fission yeast homolog of the human protein ataxia telangiectasia mutated (ATM; Savitsky et al. 1995). Fission yeast Chk1 phosphorylates $\mathrm{Cdc} 25$ at a serine residue within the region of the protein that binds to Rad24 and Rad25, fission yeast homologs of mammalian 14-3-3 protein, suggesting that Chk1 acts by regulating the binding of $\mathrm{Cdc} 25$ to $\operatorname{Rad} 24$ and $\operatorname{Rad} 25$ (Furnari et al. 1997; Zeng et al. 1998). Given that Cdc25 is relocated from the nucleus to the cytoplasm as a result of its binding to 14-3-3 protein (Dalal et al. 1999; Kumagai and Dunphy 1999; Lopez-Girona et al. 1999), Chk1 may indirectly inhibit Cdc25 activity in the nucleus in response to DNA damage.

A mammalian homolog of Chk1 has been shown to phosphorylate Cdc25A, -B, and -C (Peng et al. 1997; Sanchez et al. 1997). In human cells, Chk1 is expressed from $S$ phase to $M$ phase of the cell cycle as an active kinase (Kaneko et al. 1999), suggesting that Chk1 may regulate the timing of mitosis by controlling the activity of Cdc25 during the normal cell cycle. In addition, a Drosophila Chk1 homolog, Grapes, modulates cell cycle timing at the midblastula transition during embryogenesis (Sibon et al. 1997).

To clarify the physiological roles of Chk1 in the regulation of mammalian cell cycle and checkpoint mechanisms, we generated Chk1-deficient $\left(\mathrm{Chk}^{-/-}\right)$mutant 
Takai et al.

mice. Analysis of $\mathrm{Chk}^{-/-}$embryos suggests that Chk1 is required for cell cycle arrest in response to DNA replication block and DNA damage in mammals.

\section{Results}

Inactivation of Chk1 results in early embryonic death

To clarify whether mammalian Chk1 is involved in certain checkpoint mechanisms, we generated Chk1-deficient $\left(C h k 1^{-/-}\right)$mutant mice by gene targeting in embryonic stem (ES) cells. The targeting vector was designed to delete $2.5 \mathrm{~kb}$ of genomic DNA containing exons 1 and 2 of Chk1 (Fig. 1A). The deleted exons contain the initiation sites for both transcription and translation, and they encode an ATP-binding region of the kinase. Thus, functional Chk1 was not expected to be expressed from the mutated allele. The targeting construct was introduced by electroporation into ES cells, and 9 of 128 resulting G418- and gancyclovir-resistant colonies were shown to be heterozygous for the Chk1 locus (Fig. 1B). Four of these targeted ES clones were used to generate chimeric mice. Chimeras produced from EX104 and EX226 clones were backcrossed to strain C57BL/6J animals to generate mice heterozygous for the Chk1 allele. Adult Chk1 heterozygous $\left(\mathrm{Chk}^{+/-}\right)$mice were overtly normal, and no defect in the proliferation of embryonic fibroblasts from these animals was apparent (data not shown). We then intercrossed $\mathrm{Chk}^{+/-}$mice and determined the geno- types of 90 of the resulting offspring by polymerase chain reaction (PCR) analysis of tail DNA at age 3 weeks. No $C h k 1^{-/-}$animals were detected among these offspring (Table 1). Given that mortality of neonates was not noticed during the first 3 weeks after birth, this lack of Chk $1^{-1-}$ mice indicated that Chk1 deficiency results in embryonic death.

We therefore investigated the time of the presumptive embryonic mortality in $C h k 1^{-/-}$mice by analyzing the genotypes of embryos from heterozygote intercrosses at various stages of embryogenesis. PCR analysis of postimplantation embryos dissected from the decidua at embryonic day (E) 10.5 to E11.5 (with the morning of vaginal plug detection corresponding to E0.5) or E7.5 showed that none of these embryos were $C h k 1^{-/-}$(Table 1; Fig. 1C). However, empty deciduae, which could account for the absence of $C h k 1^{-/-}$embryos, were detected at E7.5 and between E10.5 and E11.5. The genotypes determined by PCR were confirmed by Southern blot analysis, indicating the reliability of the PCR assay. At E3.5, Chk1 $1^{-/-}$ blastocysts were detected in a ratio expected for a Mendelian distribution (Table 1), suggesting that $C h k 1^{-/-}$ embryos die between E3.5 and E7.5.

\section{Aberrant nuclear morphology and defective growth} in $\mathrm{Chk}^{-/-}$embryos

To analyze further the early embryonic mortality of $C h k 1^{-/-}$mice, we examined the morphology of embryos
Figure 1. Targeted disruption of mouse Chk1. (A) Structure of the targeting vector pVT-Chk1N (1), restriction map of the mouse Chk1 locus (2), and structure of the mutated locus after homologous recombination (3). The coding and noncoding exons are numbered and depicted by closed and open boxes, respectively. HindIII sites other than those shown also exist in the locus. The mutated Chk1 allele was detected by PCR with a set of primers, c and d, shown as arrowheads, and by Southern blot analysis, with a $5^{\prime}$ probe shown as a bold line. The expected sizes of the $\mathrm{XbaI}$ fragments that hybridize with the probe on Southern analysis are indicated for the wild-type and mutant Chk1 alleles (4). (PGK-neo) Neomycin transferase gene linked to the phosphoglycerate kinase (PGK) gene promoter; (PGK-tk) thymidine kinase gene of herpes simplex virus linked to the PGK gene promoter; (B) BamHI; (E) EcoRI; (C) ClaI; (Xb) XbaI; (H) HindIII. (B) Southern blot analysis of genomic DNA from targeted ES clones EX104 and EX226. Genomic DNA from individual ES clones was digested with $\mathrm{XbaI}$ and hybridized with the $5^{\prime}$ probe. The 8.2 -kb fragment corresponding to the wild-type (WT) allele and the 7.0$\mathrm{kb}$ fragment corresponding to the mutated (KO, knockout) allele are indicated. (C) Genotype analysis by Southern blot analysis (top) and PCR (bottom) of E11.5 embryos from heterozygote intercrosses. DNA samples were subjected to PCR with primers a and b for the wild-type (WT) allele and with primers $\mathrm{c}$ and $\mathrm{d}$ for the mutated (KO) allele, yielding amplification products of 0.9 and $1.5 \mathrm{~kb}$, respectively.

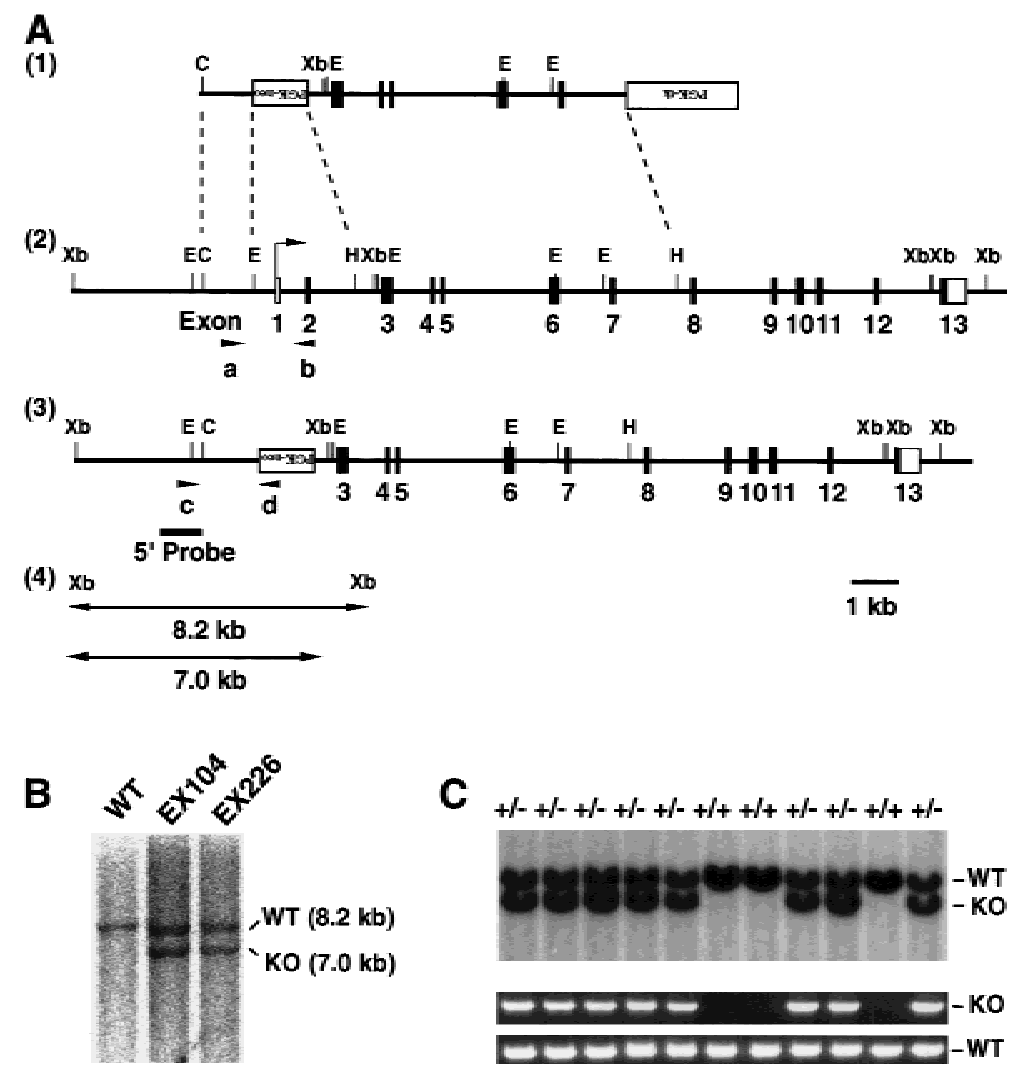


Table 1. Genotypes of neonates and embryos from $\mathrm{Chk}^{+/-}$ heterozygote intercrosses

\begin{tabular}{|c|c|c|c|c|c|}
\hline Age & Chk1 $^{+/+}$ & Chk1 $1^{+/-}$ & Chk $1^{-1-}$ & $\begin{array}{l}\text { Empty } \\
\text { deciduae }\end{array}$ & Total \\
\hline E3.5 & 32 & 62 & 30 & & 124 \\
\hline E7.5 & 11 & 18 & 0 & 7 & 36 \\
\hline E10.5-11.5 & 5 & 13 & 0 & 3 & 21 \\
\hline $\begin{array}{l}3 \text { weeks } \\
\text { after birth }\end{array}$ & 27 & 63 & 0 & & 90 \\
\hline
\end{tabular}

Embryos from $C h k 1^{+/-}$heterozygote intercrosses were collected on the indicated embryonic days, and the genotypes were determined by Southern blot analysis with the $5^{\prime}$ probe or PCR with primers a and b or primers $c$ and d (Figure 1A). Neonates were genotyped by PCR with the same primer pairs.

at different stages of development. Although $\mathrm{Chk} 1^{-/-}$ blastocysts appeared normal, nuclear staining with $4^{\prime}, 6$ diamidino-2-phenylindole (DAPI) showed the presence of aberrant nuclei containing highly condensed aggregates of chromatin or irregularly-sized micronuclei. The nuclear abnormalities were first detected at E3.5 and were more prominent at E4.0 in Chk1 $1^{-/-}$embryos (Fig. 2A-H). Aberrant nuclei were detected predominantly within the inner portion of embryos, where cells are dividing rapidly. No such nuclear abnormalities were apparent in $\mathrm{Chk}^{+/-}$embryos (Fig. 2I-P). Analysis of nuclei from 72 embryos at E3.5 is summarized in Table 2. A substantial proportion $(85.7 \%)$ of $\mathrm{Chk1}^{-1-}$ embryos contained abnormal nuclei, whereas nuclei appeared normal
Table 2. Frequency of abnormal nuclei in E3.5 preimplantation embryos

\begin{tabular}{lccc}
\hline Genotype & $\begin{array}{c}\text { Normal } \\
\text { nuclei }\end{array}$ & $\begin{array}{c}\text { Abnormal } \\
\text { nuclei }\end{array}$ & Total \\
\hline Chk $1^{+/+}$ & 17 & 0 & 17 \\
Chk1 $1^{+/-}$ & 34 & 0 & 34 \\
Chk1 $^{-/-}$ & 3 & 18 & 21 \\
\hline
\end{tabular}

Embryos from $\mathrm{Chk1}^{+/-}$heterozygote intercrosses were stained with DAPI and analyzed by microscopy under ultraviolet light. The number of embryos of each genotype containing abnormal nuclei (highly condensed chromatin aggregates or irregular micronuclei; Figure 2F) was determined.

in all Chk $1^{+/+}$and $C h k 1^{+/-}$embryos examined. These results indicated that loss of Chk1 function results in gross changes in nuclear morphology, which may be directly responsible for the arrested development of Chk1 $1^{-/-}$mice.

The predominant localization of aberrant nuclei in rapidly dividing cells suggested that Chk1 deficiency could affect embryonic cell proliferation. To assess directly the growth capability of $C h k 1^{-1-}$ embryos, we collected E3.5 blastocysts from heterozygous intercrosses and cultured them individually in vitro for 4 days, during which time they formed outgrowths. Both $C h k 1^{+/-}$and Chk $1^{-/-}$blastocysts hatched, attached to the culture dish, and produced apparently normal trophoblast giant cells, suggesting that $\mathrm{Chk} 1^{-/-}$blastocysts are capable of implanting in the uterus (Fig. 3). However, the inner cell
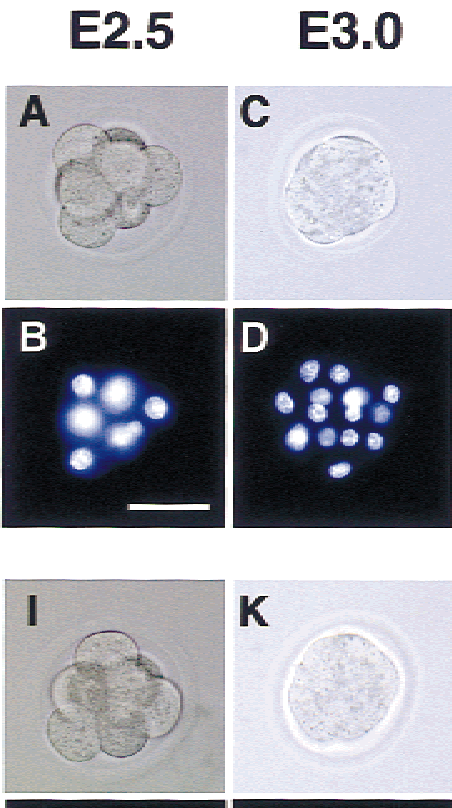

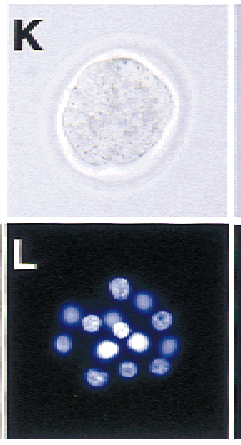

E3.0
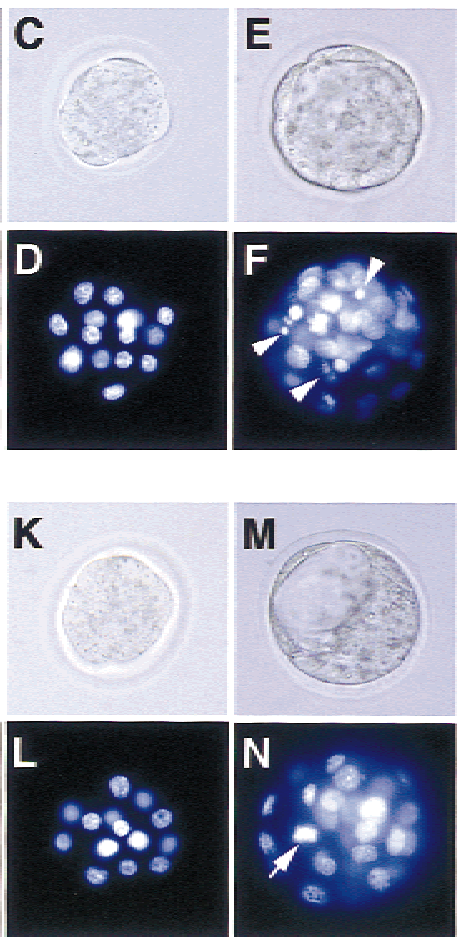

E4.0
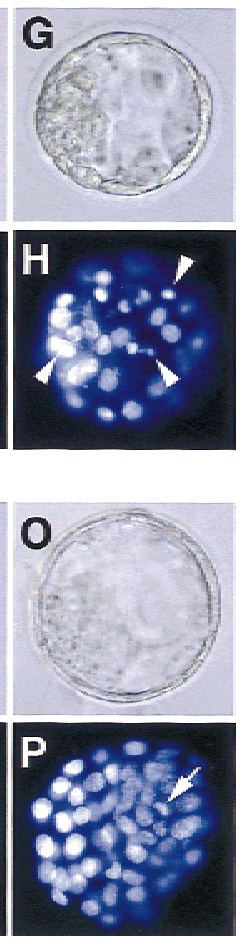

Figure 2. Morphological analysis of DAPI-stained Chk1 $1^{-1-}$ and $\mathrm{Chk}^{+/-} \mathrm{em}$ bryos. Embryos from $C h k 1^{+/-}$heterozygote intercrosses were isolated at the indicated embryonic days, fixed, and stained with DAPI. Chk $1^{-1-}$ embryos at E3.5 and E4.0 contained abnormal nuclei, indicated by arrowheads. Mitotic nuclei $(N$ and $P$, arrows) were distinguished from abnormal nuclei by microscopic observation. The genotypes of embryos were determined by PCR. Images were obtained under bright-field conditions $(A, C, E, G, I, K, M, O)$ or under ultraviolet illumination $(B, D, F$, $H, J, L, N, P)$. Bar, $50 \mu \mathrm{m}$. 
Takai et al.

Figure 3. Defective growth of $C h k 1^{-/-}$ blastocysts in vitro. $C h k 1^{+/-}(A)$ and Chk1 $1^{-/-}(B)$ blastocysts were removed at E3.5 and cultured for 4 days, during which time they developed outgrowths. The inner cell mass (ICM) grew normally and was surrounded by trophoblast giant cells (TG) in $C h k 1^{+/-}$blastocysts. In contrast, the inner cell mass was completely absent in $C h k 1^{-/-}$blastocysts. Bar, $50 \mu \mathrm{m}$.
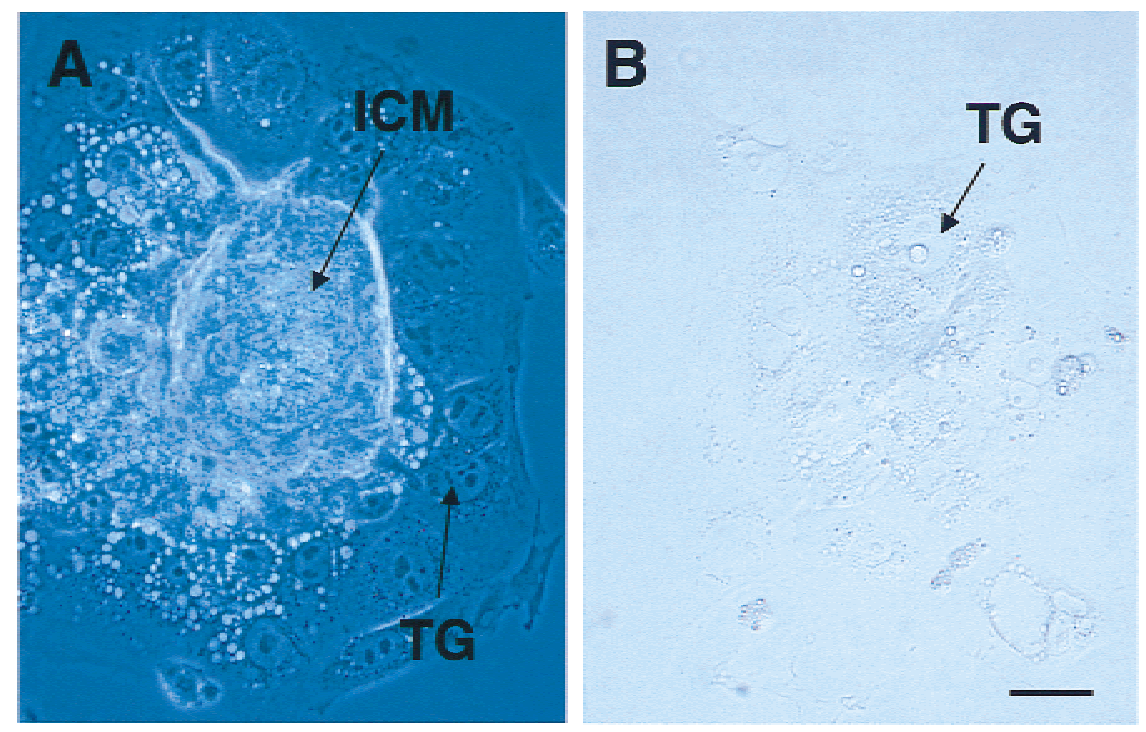

mass did not grow in Chk1-/- blastocysts (Fig. 3; Table 3), whereas it appeared to grow normally in all $C h k 1^{+/+}$ and $\mathrm{Chk}^{+/-}$blastocysts. Some embryos could not attach to the culture dish or died during in vitro culture (genotype unknown in Table 3), suggesting the smaller number of abnormal outgrowth in $\mathrm{Chk}^{--}$blastocysts than those expected. In addition, numerous attempts to generate $C h k 1^{-/-}$ES cells by increasing the concentration of G418 or by using a second targeting vector with a hygromycin resistance gene cassette were unsuccessful (data not shown), suggesting that Chk1 is indispensable for ES cell proliferation. Taken together, the results from these in vitro experiments directly support a generalized fail-

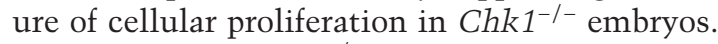

The cause of $\mathrm{Chk}^{-1-}$ embryonic death was then explored by terminal deoxytransferase-mediated deoxyuridine nick end-labeling (TUNEL) staining of blastocysts. TUNEL-positive cells were readily detected in Chk $1^{-/-}$ embryos, but they were not apparent in $C h k 1^{+/-}$embryos, indicating that $C h k 1^{-/-}$embryonic death is, at least in part, due to apoptosis (Fig. 4).

\section{Defective checkpoints in $\mathrm{Chk}^{-/-}$embryos}

Given that Chk1 functions in signaling associated with cell cycle checkpoints in yeast, the aberrant nuclei in Chk $1^{-1-}$ embryos may have reflected defects in cell cycle checkpoint functions. To examine this possibility, we investigated the effects of inhibition of DNA replication or DNA damage on the cell cycle arrest in $C h k 1^{-1-}$ embryos; one would expect that such DNA replication block or DNA damage would arrest the cell cycle before

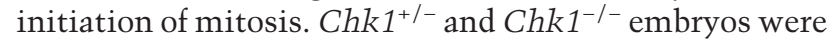
treated with aphidicolin, $\mathrm{X}$ ray, or ultraviolet radiation (UV), followed by nocodazole treatment to avoid progression of the cell cycle to the next $\mathrm{G}_{1}$. To detect the mitotic cells, the treated embryos were subjected to immunostaining with antibodies specific for histone $\mathrm{H} 3$ phos- phorylated at Ser ${ }^{10}$, which is an M-phase-specific marker (Ajiro et al. 1996). Phosphohistone H3-positive cells were markedly increased after nocodazole treatment without DNA replication block or DNA damage, confirming that nocodazole effectively arrest the cell cycle at M phase (Fig. 5C,F). Although mitotic cells were barely detected in the $\mathrm{Chk1}^{+/-}$embryos treated with aphidicolin, X ray, or UV (Fig. 5I,O,U), indicating that these treatments effectively induced cell cycle arrest before mitosis, they were readily apparent in the treated Chk1 $1^{-1-}$ embryos (Fig. 5L, R,X). These results are summarized in Figure 6. After 3 hours of treatment with nocodazole, $17 \%, 13 \%$, and $34 \%$ of cells were phosphohistone H3-positive in $\mathrm{Chk1}^{+/+}, \mathrm{Chk1}^{+/-}$, and $\mathrm{Chk}^{-/-}$ blastocysts, respectively. With aphidicolin, $\mathrm{X}$ ray, and UV treatment, phosphohistone H3-positive cells were dramatically decreased in $\mathrm{Chk1}^{+/-}$and $\mathrm{Chk}^{+/+}$blastocysts $(<7 \%)$ but did not change in $\mathrm{Chk}^{-/-}$blastocysts $(>16 \%)$. Thus, these results clearly demonstrated that Chk1 is indispensable for cell cycle arrest before mitosis in response to DNA replication block and DNA damage.

Because aphidicolin can stall the replication forks when it is applied to S-phase cells and stalling of the replication fork is known to cause double-stranded breaks on the lagging strand of the newly synthesized

Table 3. Genotypic and phenotypic analysis of blastocysts from $\mathrm{Chk} 1^{+/-}$intercrosses cultured in vitro

\begin{tabular}{lrrcc}
\hline Phenotype & Chk1 $^{+/+}$ & Chk1 $^{+/-}$ & Chk1 $^{-/-}$ & Unknown $^{a}$ \\
\hline Normal & 27 & 49 & 0 & 1 \\
Abnormal & 0 & 0 & 8 & 15 \\
Total & 27 & 49 & 8 & 16 \\
\hline
\end{tabular}

Blastocysts were collected at E3.5 from $\mathrm{Chk} 1^{+/-}$intercrosses and cultured individually for 4 days. Embryos were scored as abnormal if the inner cell mass did not develop. The genotype was subsequently determined by PCR.

${ }^{a}$ Genotype could not be determined. 
DAPI
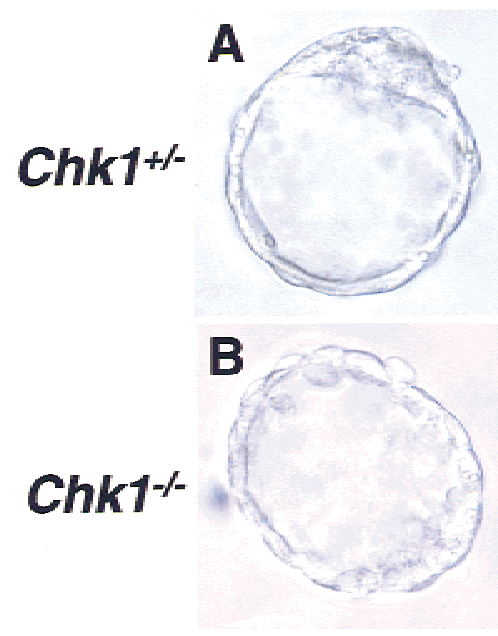
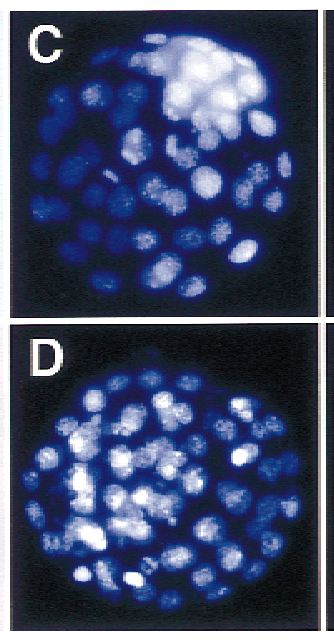

\section{TUNEL}

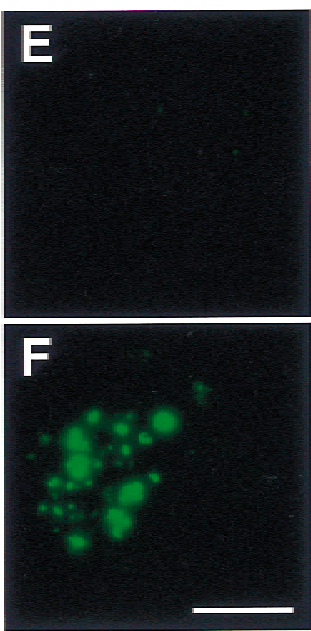

Figure 4. Chk1 deficiency resulted in apoptotic cell death in blastocysts. Chk $1^{+/-}$ and $C h k 1^{-1-}$ blastocysts were isolated at E3.5. The fixed blastocysts $(A, B)$ were stained with TUNEL $(E, F)$ and DAPI $(C, D)$. Bar, $50 \mu \mathrm{m}$.
DNA, aphidicolin treatment could also activate the DNA damage checkpoint and the DNA replication checkpoint. To confirm the Chk1 function in the DNA replication checkpoint, we examined whether this protein is subject to posttranslational modification in response to DNA replication block. Normal fibroblasts were synchronized at $S$ phase and treated with either aphidicolin or hydroxyurea (HU), and modification of Chk1 and Chk2 (Cds1) proteins was assessed by immunoblot analysis. Treatment with either aphidicolin or HU induced a decrease in the electrophoretic mobility of Chk1 that was apparent as early as $1 \mathrm{hr}$ after exposure to these agents (data not shown). In contrast, the mobility of Chk2 was not apparent after treatment with HU or aphidicolin, although it was slightly reduced at $24 \mathrm{hr}$ after treatment (data not shown). Given that Chk2 is rapidly phosphorylated in response to double-stranded breaks, Chk1 phosphorylation may not be due to the activated DNA damage checkpoint. Thus, these results are consistent with a role for Chk1 in the DNA replication checkpoint in mammalian cells.

\section{Discussion}

The early embryonic death of $C h k 1^{-/-}$mice indicates that Chk1 is essential for cell growth and differentiation

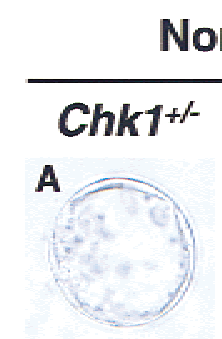

None
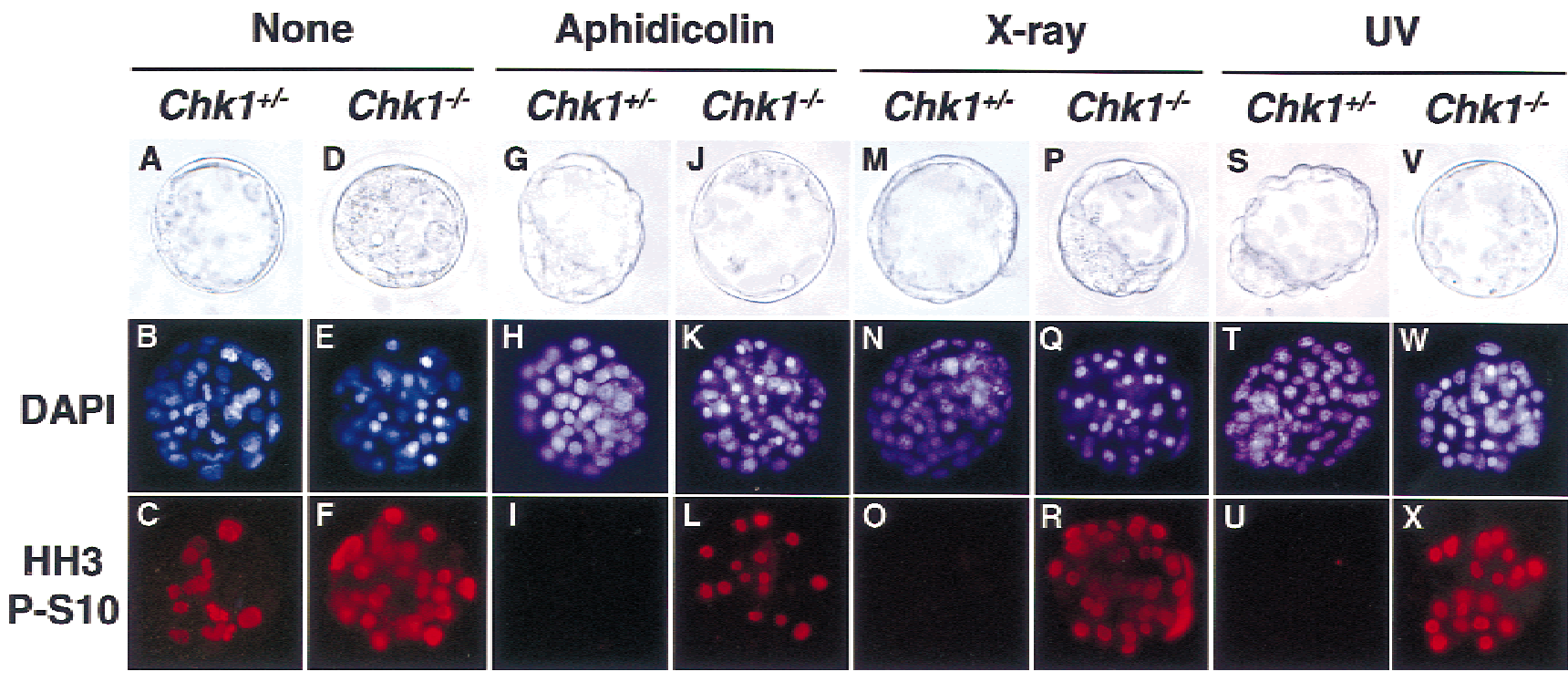

Figure 5. Abrogated $\mathrm{G}_{2}$ checkpoints in $C h k 1^{-/-}$embryos. Chk $1^{+/-}$and $C h k 1^{-/-}$blastocysts at E3.5 were either not treated $(A-F)$ or were treated with $1 \mu \mathrm{M}$ aphidicolin $(G-L)$, X ray $(10 \mathrm{~Gy} ; M-R)$, or UV $\left(0.07 \mathrm{~J} / \mathrm{cm}^{2} ; S-X\right)$. Three hours after treatment, embryos were incubated with nocodazole $(0.1 \mathrm{\mu g} / \mathrm{ml})$ for an additional $3 \mathrm{hr}$ and then fixed and stained with antibody specific to phosphohistone H3 at $\operatorname{Ser}^{10}$ (HH3 P-S10; $\left.C, F, I, L, O, R, U, X\right)$ and DAPI $(B, E, H, K, N, Q, T, W)$. The genotypes of each embryo were determined by PCR. Images were obtained under either bright-field conditions or ultraviolet illumination. 


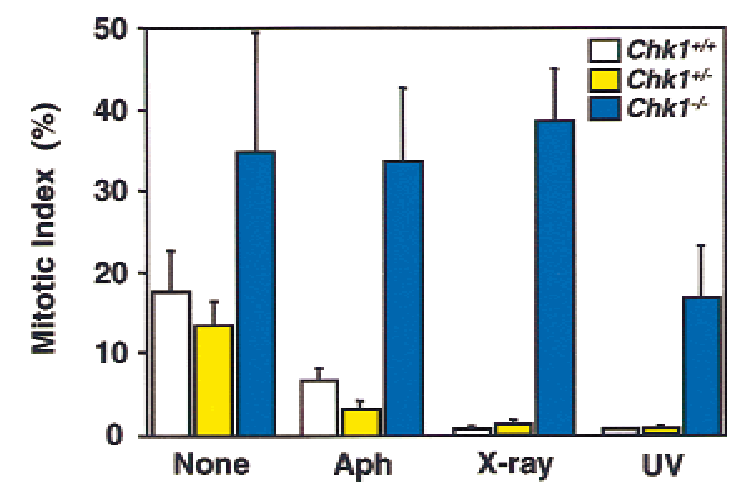

Figure 6. DNA replication block and DNA damage reduced mitotic index in $\mathrm{Chk1}^{+/+}$or $\mathrm{Chk1}^{+/-}$embryos but not in $C h k 1^{-/-}$embryos. The mitotic index was determined by counting the phosphohistone $\mathrm{H} 3$-positive cells and was represented as a percentage of the phosphohistone H3-positive cells in total cells. Treatment with aphidicolin (Aph), X ray, and UV was as described in Fig. 5. The values are shown as mean \pm S.D. $(n=6)$.

at an early stage of development. We previously showed that Chk1 is specifically expressed from $S$ to $M$ phase of the cell cycle as an active kinase and that it phosphorylates Cdc25C at Ser ${ }^{216}$ even in the absence of DNA damage, thereby preventing the nuclear accumulation of Cdc25C during this period (Kaneko et al. 1999). Thus, a defect in Chk1 function is likely to result in premature accumulation of $\mathrm{Cdc} 25 \mathrm{C}$ in the nucleus and consequent premature activation of cyclin B-Cdc2. Because early embryonic cells proliferate with short doubling times, Chk1 deficiency may abrogate a high degree of precision in transition mechanisms from $\mathrm{S}$ to $\mathrm{M}$ phase. This hypothesis is supported by the similarity between the mi-

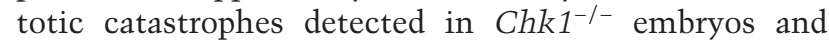
those in cells transfected with vectors encoding cyclin B and Cdc2 (Heald et al. 1993). Interestingly, $A T R^{-/-}$embryos have also been reported to show similar early embryonic death and mitotic catastrophes (Brown and Baltimore 2000), suggesting a link between ATR and Chk1. Consistent with that report, an essential role for ATR in DNA replication checkpoint responses has been implied (Cliby et al. 1998; Chaturvedi et al. 1999; Sarkaria et al. 1999). In addition, because $B R C A 1^{-1-}$ and $B R C A 2^{-/-}$ mice die early in the development stage and show defects in cellular proliferation similar to those observed in Chk $1^{-1-}$ blastocysts (Hakem et al. 1996; Sharan et al. 1997; Suzuki et al. 1997), there may be a link between Chk1 and the functions of BRCA1 and BRCA2. In this regard, Chk2 (Cds1) has recently been reported to phosphorylate BRCA1 in response to DNA damage, and this phosphorylation is essential for BRCA1 functions (Lee et al. 2000). Therefore, Chk1 may also phosphorylate BRCA1 or BRCA2 in response to DNA damage or DNA replication block and thus regulate their functions.

However, the death of $\mathrm{Chk}^{-/-}$mouse embryos at an early developmental stage contrasts with the observation that Chk1 mutants of fission yeast are viable and retain apparently normal response to DNA replication block but lack response to DNA damage (Walworth et al.
1996). Budding yeast Chk1 has recently been reported to act in the DNA damage checkpoint through a distinct mechanism that maintains the abundance of Pds1/Cut2 (Sanchez et al. 1999). Chk1 mutant of budding yeast is also viable and retains apparently normal response to DNA replication block but is mildly sensitive to DNA damage induced by ionizing irradiation. However, in fission yeast, Chk1 is essential for the DNA replication checkpoint in the absence of Cds1, suggesting that Cds1 may complement Chk1 function in the DNA replication checkpoint (Lindsay et al. 1998; Zeng et al. 1998; Brondello et al. 1999). Consistent with this finding, Chk1 and Cds1 double mutants are far more sensitive than the single mutants to both DNA damage and DNA replication block. In contrast, Cds1 is unlikely to complement Chk1 function in DNA replication checkpoint in mammals, given the observations that, unlike fission yeast Cds1, mammalian Cds1 is not rapidly phosphorylated in response to DNA replication block (Matsuoka et al. 1998; Brown et al. 1999; Chaturvedi et al. 1999; Tominaga et al. 1999). Thus, the differences in the lethality of Chk1 mutant cells between mammals and yeast may be explained by the defective function in the DNA replication checkpoint. This idea is supported by the fact that the Drosophila Chk1 mutant, Grapes (Sibon et al. 1997), and the ATR homolog, Mei-41, mutant (Sibon et al. 1999) die at the midblastula transition, showing a defect in DNA replication checkpoint function. Thus, given that early embryonic cells proliferate with a very short $\mathrm{G}_{2}$ phase, Chk1 may be particularly important in early embryonic development.

\section{Materials and methods}

\section{Construction of the Chk1 targeting vector}

The mouse Chk1 gene (Chk1) was isolated by screening a mouse 129/Sv Lambda FIX II Genomic Library (Stratagene) with mouse Chk1 cDNA as a probe. Five overlapping genomic clones containing exons 1-13 of Chk1 were isolated and subcloned into the pBluescript II SK (+) vector (Stratagene). The targeting vector pTV-Chk1N was designed to replace a $2.5-\mathrm{kb}$ EcoRI-HindIII genomic fragment containing exons 1 and 2 of Chk1 with a PGK-neo poly(A) cassette in the orientation opposite to that of Chk1 transcription (Nakayama et al. 1993); a similar targeting vector, pTV-Chk1H, was designed to replace the same genomic fragment with a PGK-hyg-poly(A) cassette. The targeting vector was constructed with the $1.3-\mathrm{kb} C l a \mathrm{I}-E c o R I$ fragment as the right arm and the 7-kb HindIII fragment as the left arm. The PGK-tk-poly(A) cassette (Tybulewicz et al. 1991) was placed downstream of the HindIII fragment to allow for enrichment of targeted ES cells.

\section{Electroporation and selection of ES cells}

ES cells from E14 mice of strain 129/Ola were maintained on a monolayer of X-irradiated and neomycin-resistant embryonic fibroblasts in cES medium, comprising Dulbecco's Modified Eagle's Medium (DMEM; GIBCO BRL) supplemented with leukemia inhibitory factor (1000 U/ml; GIBCO BRL), 15\% heat-inactivated fetal bovine serum (FBS; Hyclone), 2 mM L-glutamine, $1 \mathrm{~mm}$ sodium pyruvate (GIBCO BRL), $0.1 \mathrm{~mm}$ DMEM nonessential amino acid solution (GIBCO BRL), penicillin G (100 
$\mathrm{U} / \mathrm{ml})$, streptomycin sulfate $(100 \mu \mathrm{g} / \mathrm{ml})$, and $50 \mu \mathrm{M} \beta$-mercaptoethanol (Nakayama et al. 1993). The targeting vector (20 $\mu \mathrm{g})$ was linearized by digestion with SalI and then introduced by electroporation into $2 \times 10^{7}$ ES cells with a Gene Pulser (two pulses of $0.3 \mathrm{kV}$ and $125 \mu \mathrm{F}$; Bio-Rad). The cells were subsequently cultured for 7 days in the presence of G418 $(0.3 \mathrm{mg} / \mathrm{ml})$ and $2 \mu \mathrm{M}$ gancyclovir. Homologous recombinant ES clones were identified by PCR with primers c and d, which are specific for the Chk1-flanking sequence of the targeting construct $\left(5^{\prime}\right.$-TATGCCTCGTTTCACTACTATTCC-3') and for the PGK-neo cassette (5'-GGGTGGGGTGGGATTAGATAAATG-3'), respectively. The results of PCR screening were confirmed by Southern blot analysis: DNA prepared from PCR-positive ES clones was digested with $\mathrm{XbaI}$, transferred to a nylon membrane (Amersham Pharmacia Biotech), and subjected to hybridization with the 390-bp 5' probe that flanked the 5' homology region (Fig. 1A). The expected sizes for wild-type and mutant Chk 1 hybridizing fragments are 8.2 and $7.0 \mathrm{~kb}$, respectively (Fig. 1B). The frequency of homologous recombination was $7.0 \%$ of the doubly resistant ES clones.

\section{Generation of chimeric mice}

Chimeric mice were generated by microinjection of four independent targeted ES clones, including EX104 and EX226, into C57BL/6J host blastocysts, which were then implanted into pseudopregnant ICR foster females. The resulting male offspring that showed a high level of chimerism, as shown by coat color, were mated to C57BL/6J females to generate mice heterozygous for the mutant Chk1 allele. Germ-line transmission of the mutant allele was tested by PCR and verified by Southern blot analysis (under the same conditions as those described for the detection of homologous recombination in ES cells) of tail DNA from $F_{1}$ offspring with agouti coat color. Mutant mice were obtained from two independent targeted clones (EX104 and EX226), with the animals from both lines showing identical phenotypes. All mice were maintained in a specific pathogenfree animal facility at the National Institute for Longevity Sciences.

\section{Blastocyst culture}

Heterozygous male and female mutant mice were bred to obtain wild-type $\left(\mathrm{Chk}^{+/+}\right)$, heterozygous $\left(\mathrm{Chk}^{+/-}\right)$, and homozygous mutant $\left(\mathrm{Chk}^{-/-}\right)$mouse embryos. The morning of the day on which a vaginal plug was detected was designated E0.5. Embryos at different stages of development (E1.5-E4.0) were collected by flushing oviducts or the uterus with HEPES-buffered medium 2 (M2; Sigma). Embryos were fixed immediately for 20 min at $4^{\circ} \mathrm{C}$ with phosphate-buffered saline (PBS) containing $4 \%$ paraformaldehyde, and their nuclei were stained with DAPI (Vectashield, Vector). In some experiments, embryos were cultured in the presence of drugs or dimethyl sulfoxide (DMSO) for several hours. For in vitro culture, blastocysts were cultured for 4 days in tissue culture plates containing cES medium without leukemia inhibitory factor; outgrowths were inspected daily and photographed to monitor their development.

\section{Genotyping of preimplantation embryos}

Individual embryos and cells from outgrowths in culture were lysed by incubation at $55^{\circ} \mathrm{C}$ for $3 \mathrm{hr}$ in $20 \mu \mathrm{l}$ of PCR lysis buffer [10 mM Tris- $\mathrm{HCl}$ at $\mathrm{pH} 8.4,50 \mathrm{~mm} \mathrm{KCl}, 2 \mathrm{~mm} \mathrm{MgCl}_{2}, 0.45 \%$ (vol/vol) NP-40, 0.45\% (vol/vol) Tween 20] containing proteinase $\mathrm{K}(60 \mu \mathrm{g} / \mathrm{ml})$. After boiling for $10 \mathrm{~min}$, a portion $(8 \mu \mathrm{l})$ of the lysates was subjected to PCR amplification. A $1.5-\mathrm{kb}$ product was expected for the mutant Chk1 allele with the primers c and $\mathrm{d}$ (see above). Primers a and b, which are specific for the sequence upstream of Chk1 (5'-TTAGAAGGAAGGGTCCTTGC-3') and for a sequence within exon 2 of Chk1 (5'CAGTCTTCCACAAAAGGCAC-3'), respectively, were used to detect the wild-type allele. The amplification protocol comprised an initial incubation at $94^{\circ} \mathrm{C}$ for $5 \mathrm{~min}$, followed by 45 cycles of $94^{\circ} \mathrm{C}$ for $1 \mathrm{~min}, 64^{\circ} \mathrm{C}$ for $1 \mathrm{~min}$, and $72^{\circ} \mathrm{C}$ for $90 \mathrm{sec}$.

\section{Immunocytochemistry and TUNEL staining}

Embryos were fixed with 4\% paraformaldehyde in PBS for 20 min at $4^{\circ} \mathrm{C}$ and then permeabilized for $20 \mathrm{~min}$ at room temperature with PBS containing $0.3 \%$ (vol/vol) Triton X-100 and $1.5 \%$ (wt/vol) bovine serum albumin. The treated embryos were double stained in the same solution with DAPI and treated with antibody specific to phosphohistone $\mathrm{H} 3$ at $\operatorname{Ser}^{10}$ (1:200 dilution; Upstate Biotechnology), followed by Cy-3 conjugated secondary antibody to rabbit IgG 1:200 dilution; Jackson ImmunoResearch). DNA fragmentation associated with apoptosis was detected with an in situ cell death detection kit (Roche). In brief, permeabilized embryos were labeled with the TUNEL reaction mixture for $60 \mathrm{~min}$ at $37^{\circ} \mathrm{C}$. Fluorescein-labeled DNA was analyzed using a fluorescence microscope.

\section{Cell culture and immunoblot analysis}

Human diploid fibroblasts (MJ-90) were maintained in DMEM supplemented with $10 \%$ heat-inactivated FBS (GIBCO BRL), as described previously (Nakanishi et al. 1995). MJ-90 cells cultured in 90-mm dishes were lysed with $0.5 \mathrm{ml}$ of IP kinase buffer [50 mM HEPES- $\mathrm{NaOH}$ at $\mathrm{pH} 8.0,150 \mathrm{~mm} \mathrm{NaCl}, 25 \mathrm{~mm}$ EGTA, $1 \mathrm{~mm}$ EDTA, $0.1 \%$ Tween 20, 10\% (vol/vol) glycerol] containing a mixture of protease inhibitors (soybean trypsin inhibitor, $20 \mu \mathrm{g} / \mathrm{ml}$; aprotinin, $2 \mu \mathrm{g} / \mathrm{ml}$; leupeptin, $5 \mu \mathrm{g} / \mathrm{ml}$; and phenylmethylsulfonyl fluoride, $100 \mu \mathrm{g} / \mathrm{ml}$ ) and phosphatase inhibitors $\left(50 \mathrm{~mm} \mathrm{NaF}, 0.1 \mathrm{mM} \mathrm{Na}_{3} \mathrm{VO}_{4}\right.$, and $5 \mathrm{mg} / \mathrm{ml}$ phosphatase substrate). A portion of the resulting lysate $(100 \mu \mathrm{l})$ was then fractionated by SDS-polyacrylamide gel electrophoresis and subjected to immunoblot analysis with antibodies specific for human Chk1 (1:1000 dilution; Kaneko et al. 1999) or for human Chk2 (Cds1) (1:1000 dilution; Tominaga et al. 1999). Immune complexes were detected with the ECL Plus system (Amersham).

\section{Acknowledgments}

We thank Drs. Mitsuhiro Yanagida (Graduate School of Science, Kyoto University) and Nobumoto Watanabe (Tsukuba Life Science Center, RIKEN) for discussions and critical reading of the manuscript; Dr. Shin Tanaka (National Institute for Longevity Sciences) for instructions on collecting fertilized eggs from Chk1 mutant mice; Dr. Gen Kondo (Osaka University Medical School) for advice on blastocyst culture; Kazuo Shiokawa for maintenance of Chk1 mutant mice; Kumi Tsutsumi and Yukari Yamada for technical assistance; and Kimio Kondo and Dr. Kengo Ito (Department of Radiology, National Chubu Hospital for the irradiation of embryos. This work was supported in part by a Grant-in-Aid for Scientific Research on Priority Areas (09273104 to M.N.) from the Ministry of Education, Science, Sports, and Culture of Japan and by Health Sciences Research Grants for Research on the Human Genome and Gene Therapy (H-10-genome-001 to K.I.) and for Comprehensive Research on Aging and Health (H11-chouju-005 to N.M.) from the Ministry of Health and Welfare of Japan. 
The publication costs of this article were defrayed in part by payment of page charges. This article must therefore be hereby marked "advertisement" in accordance with 18 USC section 1734 solely to indicate this fact.

\section{References}

Ajiro, K., K. Yoda, K. Utsumi, and Y. Nishikawa. 1996. Alteration of cell cycle-dependent histone phosphorylations by okadaic acid. Induction of mitosis-specific H3 phosphorylation and chromatin condensation in mammalian interphase cells. J. Biol. Chem. 271: 13197-13201.

Al-Khodairy, F. and A.M. Carr. 1992. DNA repair mutants defining G2 checkpoint pathways in Schizosaccharomyces pombe. ЕМBO J. 11: 1343-1350.

Brondello, J.M., M.N. Boddy, B. Furnari, and P. Russell. 1999. Basis for the checkpoint signal specificity that regulates Chk1 and Cds1 protein kinases. Mol. Cell. Biol. 19: 42624269.

Brown, A.L., C.H. Lee, J.K. Schwarz, N. Mitiku, H. PiwnicaWorms, and J.H. Chung. 1999. A human Cds1-related kinase that functions downstream of ATM protein in the cellular response to DNA damage. Proc. Natl. Acad. Sci. 96: 37453750.

Brown, E.J. and D. Baltimore. 2000. ATR disruption leads to chromosomal fragmentation and early embryonic lethality. Genes \& Dev. 14: 397-402.

Carr, A.M. 1996. Checkpoints take the next step. Science 271: 314-315.

Chaturvedi, P., W.K. Eng, Y. Zhu, M.R. Mattern, R. Mishra, M.R. Hurle, X. Zhang, R.S. Annan, Q. Lu, L.F. Faucette et al. 1999. Mammalian Chk2 is a downstream effector of the ATM-dependent DNA damage checkpoint pathway. Oncogene 18: 4047-4054.

Cliby, W.A., C.J. Roberts, K.A. Cimprich, C.M. Stringer, J.R. Lamb, S.L. Schreiber, and S.H. Friend. 1998. Overexpression of a kinase-inactive ATR protein causes sensitivity to DNAdamaging agents and defects in cell cycle checkpoints. EMBO J. 17: 159-169.

Dalal, S.N., C.M. Schweitzer, J. Gan, and J.A. DeCaprio. 1999. Cytoplasmic localization of human cdc25c during interphase requires an intact 14-3-3 binding site. Mol. Cell. Biol. 19: 4465-4479.

Elledge, S.J. 1996. Cell cycle checkpoints: Preventing an identity crisis. Science 274: 1664-1672.

Enoch, T. and P. Nurse. 1990. Mutation of fission yeast cell cycle control genes abolishes dependence of mitosis on DNA replication. Cell 60: 665-673.

Furnari, B., N. Rhind, and P. Russell. 1997. Cde25 mitotic inducer targeted by chk1 DNA damage checkpoint kinase. Science 277: 1495-1497.

Hakem, R., J.L. de la Pompa, C. Sirard, R. Mo, M. Woo, A. Hakem, A. Wakeham, J. Potter, A. Reitmair, F. Billia et al. 1996. The tumor suppressor gene Brcal is required for embryonic cellular proliferation in the mouse. Cell 85: 10091023.

Hartwell, L.H. and T.A. Weinert. 1989. Checkpoints: Controls that ensure the order of cell cycle events. Science 246: 629634.

Heald, R., M. McLoughlin, and F. McKeon. 1993. Human wee1 maintains mitotic timing by protecting the nucleus from cytoplasmically activated Cdc2 kinase. Cell 74: 463-474.

Kaneko, Y., N. Watanabe, H. Morisaki, H. Akita, A. Fujimoto, K. Tominaga, M. Terasawa, A. Tachibana, K. Ikeda, and M. Nakanishi. 1999. Cell-cycle-dependent and ATM-indepen- dent expression of human Chk1 kinase. Oncogene 18: 36733681.

Kumagai, A. and W.G. Dunphy. 1999. Binding of 14-3-3 proteins and nuclear export control the intracellular localization of the meiotic inducer Cdc25. Genes \& Dev. 13: 10671072.

Lee, J., K.M. Collins, A.L. Brown, C. Lee, and J.H. Chung. 2000. hCds1-mediated phosphorylation of BRCA1 regulates the DNA damage response. Nature 404: 201-204.

Lindsay, H.D., D.J. Griffiths, R.J. Edwards, P.U. Christensen, J.M. Murray, F. Osman, N. Walworth, and A.M. Carr. 1998. S-phase-specific activation of Cds1 kinase defines a subpathway of the checkpoint response in Schizosaccharomyces pombe. Genes \& Dev. 12: 382-395.

Lopez-Girona, A., B. Furnari, O. Mondesert, and P. Russel. 1999. Nuclear localization of Cdc25 is regulated by DNA damage and a 14-3-3 protein. Nature 397: 172-175.

Matsuoka, S., M. Huang, and S.J. Elledge. 1998. Linkage of ATM to cell cycle regulation by the Chk2 protein kinase. Science 282: $1893-1897$.

Nakayama, K., K. Nakayama, I. Negishi, K. Kuida, Y. Shinkai, M.C. Louie, L.E. Fields, P.J. Lucas, V. Stewart, F.W. Atl, and D.Y. Loh. 1993. Disappearance of the lymphoid system in Bcl-2 homozygous mutant chimeric mice. Science 261: $1584-1588$.

Nakanishi, M., G.R. Adami, R.S. Robetorye, A. Noda, S.F. Venable, D. Dimitrov, O.M. Pereira-Smith, and J.R. Smith. 1995. Exit from G0 and entry into the cell cycle of cells expressing p21Sdil antisense RNA. Proc. Natl. Acad. Sci. 92: 4352-4356.

Nurse, P. 1994. Ordering S phase and M phase in the cell cycle. Cell 79: 547-550.

Peng, C.Y., P.R. Graves, R.S. Thoma, Z. Wu, A.S. Shaw, and H. Piwnica-Worms. 1997. Mitotic and G2 checkpoint control: Regulation of 14-3-3 protein binding by phosphorylation of Cdc25C on serine-216. Science 277: 1501-1505.

Sanchez, Y., C. Wong, R.S. Thoma, R. Richman, Z. Wu, H. Piwnica-Worms, and S.J. Elledge. 1997. Conservation of the Chk1 checkpoint pathway in mammals: Linkage of DNA damage to Cdk regulation through Cdc25. Science 277: 1497-1501.

Sanchez, Y., J. Bachant, H. Wang, F. Hu, D. Liu, M. Tetzlaff, and S.J. Elledge. 1999. Control of the DNA damage checkpoint by Chk1 and Rad53 protein kinases through distinct mechanisms. Science 286: 1166-1171.

Sarkaria, J.N., E.C. Busby, R.S. Tibbetts, P. Roos, Y. Taya, L.M. Karnitz, and R.T. Abraham. 1999. Inhibition of ATM and ATR kinase activities by the radiosensitizing agent, caffeine. Cancer Res. 59: 4375-4382.

Savitsky, K., A. Bar-Shira, S. Gilad, G. Rotman, Y. Ziv, L. Vanagaite, D.A. Tagle, S. Smith, T. Uziel, S. Sfez et al. 1995. A single ataxia telangiectasia gene with a product similar to PI-3 kinase. Science 268: 1749-1753.

Sibon, O.C., V.A. Stevenson, and W.E. Theurkauf. 1997. DNAreplication checkpoint control at the Drosophila midblastula transition. Nature 388: 93-97.

Sibon, O.C., A. Laurencon, R. Hawley, and W.E. Theurkauf. 1999. The Drosophila ATM homologue Mei-41 has an essential checkpoint function at the midblastula transition. Curr. Biol. 9: 302-312.

Sharan, S.K., M. Morimatsu, U. Albrecht, D.S. Lim, E. Regel, C. Dinh, A. Sands, G. Eichele, P. Hasty, and A. Bradley. 1997. Embryonic lethality and radiation hypersensitivity mediated by Rad51 in mice lacking Brca2. Nature 386: 804-810.

Suzuki, A., J.L. de la Pompa, R. Hakem, A. Elia, R. Yoshida, R. Mo, H. Nishina, T. Chuang, A. Wakeham, A. Itie et al. 1997. 
Brca2 is required for embryonic cellular proliferation in the mouse. Genes \& Dev. 11: 1242-1252.

Tominaga, K., H. Morosaki, Y. Kaneko, A. Fujimoto, T. Tanaka, M. Ohtsubo, M. Hirai, H. Okayama, K. Ikeda, and M. Nakanishi. 1999. Role of human Cds1 (Chk2) kinase in DNA damage checkpoint and its regulation by p53. J. Biol. Chem. 274: 31463-31467.

Tybulewicz, V.L., C.E. Crawford, P.K. Jackson, R.T. Bronson, and R.C. Mulligan. 1991. Neonatal lethality and lymphopenia in mice with a homozygous disruption of the $\mathrm{c}$-abl protooncogene. Cell 65: 1153-1163.

Walworth, N., S. Davey, and D. Beach. 1993. Fission yeast chk1 protein kinase links the rad checkpoint pathway to cdc2. Nature 363: 368-371.

Walworth, N.C. and R. Bernards. 1996. rad-dependent response of the chk1-encoded protein kinase at the DNA damage checkpoint. Science 271: 353-356.

Zeng, Y., K.C. Forbes, Z. Wu, S. Moreno, H. Piwnica-Worms, and T. Enoch. 1998. Replication checkpoint requires phosphorylation of the phosphatase Cdc25 by Cds1 or Chk1. $\mathrm{Na}$ ture 395: 507-510. 


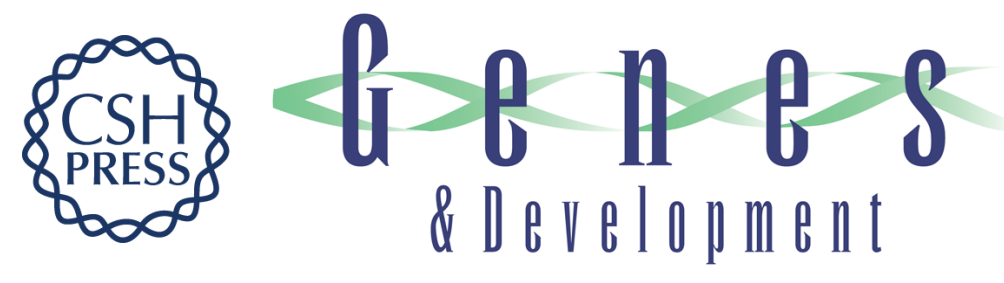

\section{Aberrant cell cycle checkpoint function and early embryonic death in Chk1 ${ }^{-1-}$ mice}

Hiroyuki Takai, Kaoru Tominaga, Noboru Motoyama, et al.

Genes Dev. 2000, 14:

Access the most recent version at doi:10.1101/gad.14.12.1439

References

This article cites 38 articles, 22 of which can be accessed free at: http://genesdev.cshlp.org/content/14/12/1439.full.html\#ref-list-1

\section{License}

Email Alerting

Receive free email alerts when new articles cite this article - sign up in the box at the top Service right corner of the article or click here.

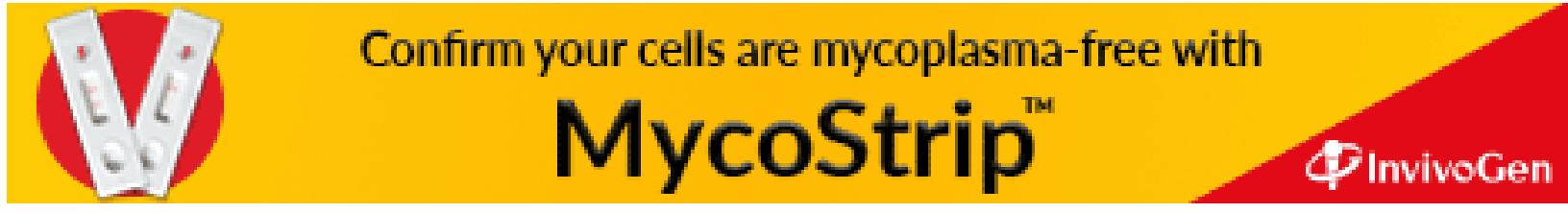

